\title{
Motivation in Foreign Language Classrooms at Tertiary Level: A Case Study
}

\section{Anh Hoang Khau ${ }^{+}$, La Pho Thach}

\section{Article history}

Received: 30 April 2021

Accepted: 26 May 2021

Published: 30 June 2021

\section{Keywords}

Foreign language, motivation, English-majored students, university, extrinsic motivation, motivational factors

\author{
Tra Vinh University, Vietnam \\ +Corresponding author•Email: anhkhau@tvu.edu.vn
}

\begin{abstract}
In teaching and learning a foreign language, especially English, motivation plays an extremely integral part in ensuring success. In this study, the researchers attempt to provide an overview of research on motivation and discover how motivation can assist second or foreign language learning in classrooms of English-majored students in the university setting. This study aims to investigate whether English-majored learners are motivated in learning English or not, focusing on extrinsic motivational factors to identify the factors to develop their motivation and maintain their journey of learning English. A questionnaire is devised and administered to 52 senior Englishmajored students. The data was then analyzed using the SPSS version 20. The results suggest that learners' motivation is related to learning facilities and teacher's personality which can encourage learners to think more positively and thus be more motivated in their language learning process. Along with providing specific recommendations for further research on motivation, the paper concludes by calling on for adopting a range of motivational factors that can promote English as a foreign or second language learning.
\end{abstract}

\section{INTRODUCTION}

In this globalization era, English is considered as an international language for communication, business, culture exchange, education, etc. It cannot be denied that English has brought to people plenty of advantages. Therefore, it has increasingly become the most desirable language to learn. Due to the demand for using English in this new world, people are not only expected to be able to speak their mother tongue but also English. Therefore, many schools around the world have placed English into a compulsory subject. In Vietnam, for example, English is also an important subject, along with other foreign language subjects such as Chinese, Japanese, etc. that high school students must pass to complete their high school education. This great demand has inspired a great deal of research on English language learning from teachers and learners, e.g. how to acquire English skills, retain vocabulary, invest in language learning, teach English more effectively and motivate learners in foreign language classes. Obviously, what can facilitate a learner to acquire a foreign language is still much debating. The facilitator can be language aptitude, age, first language and affective factors. However, in this paper, the authors emphasize the motivational factors which are predicted to very much facilitate foreign language learning. An in-depth investigation of the factors that can bring or deter motivation in foreign language learning activities is conducted. Therefore, if learning motivation can be boosted in foreign language learners, it cannot be debatable. As said by Branch (2016), "All learners, teachers, material developers, and researchers agree that motivation is an important part of mastering a second or foreign language".

Some challenges may encounter language learners due to the shortage of motivation. Lacking desire to learn causes foreign language learners many difficulties such as having unclear language learning orientation and purposes. As Huitt (2001) put it, being aware of the linguistic value will help learners enhance their motivation to learn even if they do not have enough intrinsic motivation. It can be stated that teachers should pay adequate attention to the significance of motivation in foreign language learning and certain changes may facilitate learners to improve their motivation.

This research explores a group of English-majored students' motivation during their university. In order to find out these students' motivation in their English classes, the two following research questions are proposed: (1) Are 
English majors motivated to study English at university?; (2) What factors can contribute to English majors' motivation in studying?

\section{LITERATURE REVIEW}

\subsection{Definitions of motivation}

Crookes and Schmidt (1991) stated that motivation is the learner's orientation toward learning a foreign or second language. According to Elliot and Covington (2001), motivation gives reasons for people's actions, desires, and needs. Motivation can also be defined as one's direction to behavior or what causes a person to want to imitate behavior. Pardee (1990) said that a motive encourages the person to act in a certain way or develop an inclination for a particular behavior. Oxford and Shearin (1994) defined motivation as a desire to gain an objective or work towards that objective. Narayanan (2006) said that motivation is a reason behind one's actions or behaviors. Motivation is the reason underlying behavior (Guay et al., 2010). Broussard and Garrison (2004) defined motivation as the attribute that moves us to do or not to do something. According to Gardner (1985), motivation is the combination of desire to obtain the aim of learning the language and favorable attitudes toward learning the language.

\subsection{Types of motivation}

When talking about integrative motivation, Falk (1978) thought that students who are most successful when learning a target language are those who like the people who speak the language, admire the culture and have a desire to become familiar with or even integrate into the society in which the language is used. Dörnyei (as cited in Pourhosein, Leong \& Saburi, 2012) introduced the terms intrinsic and extrinsic motivation. Intrinsic motivation refers to the motivation to engage in an activity because that activity is enjoyable to do. Extrinsic motivation refers to the actions performed to get some instrumental aims to gain a reward or stop a punishment. Brown (2000) pointed out the relationship between these two kinds of motivation. As extrinsic motivation may turn out to be integrative motivation if someone else wants the L2 learner to know the L2 for integrative purposes; extrinsic motivation may turn out to be instrumental motivation if an external power wishes the L2 learner to learn the L2 language. Instructor's autonomy-support also predicts academic performance (Black \& Deci, 2000). Autonomy-support here refers to instructors who understand and empathize with students' perspectives and allow students to make choices and initiate activities. Likewise, Miserandino (1996) found out that students with high perceived competence receive better grades in some subjects. Those who are more intrinsically motivated are more involved and persistent, participate more, and are curious about school activities. When people are free from the instruction of drives and emotions, they seek situations that interest them and require their creativity and resourcefulness (Nakata, 2006).

\subsection{Related findings regarding factors of motivation}

According to Gardner and Lambert (1972), students are motivated to improve themselves when they think of themselves as competent persons, deal with materials arranged to match their levels and see goals in their activities. Besides, they are also motivated when learners view their studies as significant and are given a difficult mission which offer them the opportunity to show psychological needs for success, recognition, and acceptance. They think that the learning is for them and not for their teachers, work with interesting materials, have an opportunity to make decisions and feel responsible for participating in activities in the faculty and school, and consequently gain experience which may bring them more success than failure. Through this process, many factors can trigger motivation and this should be brought into consideration in setting a goal. Furthermore, if learners are motivated, they can do their best to conquer a second or foreign language. If they are self-confident, they believe in overcoming difficulties (Krashan, 1976). Therefore, if the classroom teacher knows how to enourage their students to learn from errors, they can soon become more independent learners. Furthermore, anxiety, as he said, should be reduced or avoided in the classroom to create a fun atmosphere for learners to build their confidence gradually. Seda and Zahitjan (2016) found that reinforcing the learner's beliefs also motivated students, and they were more motivated when they worked and shared ideas with their classmates. Besides, based on teachers' perspective, the three most discouraging factors are related to teachers, time and classroom (Heidari \& Riahipour, 2012). This way of forming learners' beliefs can steadily help bring them motivation. Nonetheless, if unwise, the classroom teacher may discourage their students with external factors around the classroom. Gardner \& MacIntyre (1991) found in their research that motivation really had its role in second language learning. In the study of using money to encourage learners to do their best, nine out of fifty-four learners satisfied the requirements and received 10 dollars for the task. They had to go through six trials and must satisfy all the requirements in these trials which could cause stress. In this study, a 10 dollar award could just put nine participants to do their best. So, many more implicit meanings need unveiling. This small number of successful students is not satisfactory and this instrumental motivation needs reconsidering. Furthermore, Bernaus 
and Gardner (2008) obtained a positive result related to motivation when they intended to teach language teaching strategies to both teachers and students. In the correlations, they considered students as the unit of analysis of all measures of integrativeness, attitudes toward learning situation, motivation and instrumental orientations. It was revealed that students with higher levels of motivation outperformed those with lower levels of motivation on the test. Donyei (2001) had a very interesting example about motivation: A secondary school learner in Poland decided to learn Spanish (grammar lessons) in order to make a trip to Spain. He was excited to learn it at first, but he got frustrated after failure and he decided to stop. Later he was recommended with a Spanish conversation course and he could develop some basic Spanish conversational skills. Thereby, he has a feeling of accomplishment which motivated him later on. This finding can set a good example that motivation can come and go when the context changes. Perkins (2008) conducted a survey with a population of Japanese English learners in Japan at both the Senmon Gakko (a specialized school) and university level. He wanted to identify what intrinsic and extrinsic factors were included in student's motivational attitudes. Subjects involved are Senmon Gakko students (gifted students) and university students ages 18 to 22. Senmon Gakko students participated in a program somewhat equivalent to the vocational college system in North America. The students participating in the study came from a variety of academic majors. Senmon Gakko students are predicted to incline to instrumental motivation due to their course orientations. However, the results showed that these students had a firm agreement on the question, "English will be useful for my future career." First-year university students seem to be slightly more instrumentally motivated. This result supports the hypothesis that beginners are usually instrumentally oriented. Khau and Huynh (2016) researched motivation for Vietnamese non-English majors learning General English at Tra Vinh University. The study investigated the factors that can motivate them to learn General English. They explored intrinsic and extrinsic motivations. The data were collected from 60 first year non-English majors learning General English at the beginning level (equivalent Pre-A2 -Common European Framework of Reference-CEFR). The findings showed positive results in the three aspects. Students were much concerned with their basic knowledge of English, social needs, language teachers' English competence, friendly language teachers, language teachers' varied teaching methodology, wellventilated and well-equipped classrooms, and necessary teams of academic advisors. When talking about motivation, Zilmaz, Sahin, and Turgut (2017) investigated variables affecting students' motivation based on academic publications. This study did not recruit any participants, but instead it attempted to investigate variables influencing motivation through students' papers conducted on motivation. These papers include $\mathrm{PhD}$ dissertations, Masters' theses, articles and conference reports published in a period of 2000-2017 with a totality of 165 papers from 38 countries. After examining these papers, they found that teachers' majors, teachers' management skills and teaching methods affect students' motivation greatly, but parental communication, student characteristics and school fields slightly affected students' motivation. Berges (2018) conducted a study that involved 173 high school L2 students from the age of 9 to 12 about intrinsic and extrinsic motivations toward learning foreign languages. Participants completed three questions related to their reasons for learning an L2, favorite classroom materials, and teachers' behaviors. The findings revealed that six of the top ten causes for their L2 learning process were based on intrinsic factors while four were based on external factors. Furthermore, these findings revealed that students prefer to learn with materials that are associated with audio-visual resources. Finally, in terms of teachers' motivating techniques, the findings revealed that learners perceive particular teacher personality features as the most important motivators.

All these aspects have propelled the authors in this current study to introduce more questions about factors that may either encourage or discourage learners to learn a foreign language.

\section{MATERIALS AND METHODS}

\subsection{Participants}

The participants of this study are 52 third-year and four-year English majors of the School of Foreign Languages at a university including 5 males and 47 females aged between 20 and 21. During their academic pursuit of English there, they have participated in many English classes, and they have studied with many lecturers with different teaching methods and diversified classmates. Besides, they have used many facilities assisting their study and participated in the faculty or school activities and experienced academic policies at university.

\subsection{Research instrument}

The questionnaire consists of two main parts: Part one contains bio-questions and part two focuses on the two major contents centering on the two research questions. 'Are English majors motivated to study English at university?' and 'What factors can contribute to English majors' motivation in studying English?' It comprised 39 items in total, which required the respondents to rate on a five-point Likert-scale. Part 2- category 1 consists of eight 
specific questions based on the first research question 'Are English majors motivated to study English at university?' Part 2- category 2 comprises 31 specific statements based on the second research question 'What factors can contribute to English majors' motivation in studying English?' The latter includes more questions as it requires the participants to provide responses to the six factors that might promote motivation to learning English or a foreign language.

\subsection{Research procedure}

The procedure of data collection includes three phases: (1) Designing and evaluating the research instruments: The content of the questionnaire was based on the theoretical concepts in the literature review. The authors mainly designed the questions based on the extrinsic motivation defined by Dörnyei (as cited in Pourhosein, Leong, \& Saburi, 2012). He stated this type refers to the motivation coming from outside of the learners who then engage in an activity because it is enjoyable to do. The pilot survey was conducted on 10 students selected as a sample to help the researchers verify the options' reliability. After that, it was sent to a group of English teachers for feedback. The questionnaire then was edited before finally being delivered to the participants; (2) Delivering the questionnaire and collecting the participants' responses. Because most of the third-year and fourth-year classes were rushing to finish their final courses and prepare for the final examinations, it was difficult to ask for their teachers' permission for conducting the survey. Fortunately, with the help of two teachers in the faculty, the questionnaire could be conducted in about fifteen minutes (from 1:00 pm to 1:15 pm) and was finally completed by these 52 students in two days on Wednesday, June $17^{\text {th }}, 2020$ and on Thursday, June $5^{\text {th }} 2020$; (3) Analyzing the data: After collecting all the necessary data, the authors used the software SPSS version 20 to measure the reliability of the questionnaire. Then, the authors started to run the statistics for each motivation factor to have an general idea of the most and least influential motivational factors as presented in the following tables and figures.

\section{RESULTS AND DISCUSSION}

\subsection{Results}

\subsubsection{The questionnaire}

The collected results suggested that the questionnaire used in this study was reliable with the figure of Cronbach's Alpha $\alpha=0.845$ for 39 items in total.

\subsubsection{English-majored students' motivation in studying English}

There are eight items in the first part to find out whether the students are motivated to learn English or not. The table below illustrates the learner's motivation to study English.

\section{Table 1. Mean Score Showing Students' Motivation}

\begin{tabular}{cccccc}
\hline N & Minimum & Maximum & Mean & Std. Deviation \\
\hline 52 & 2.00 & 5.00 & 4.2164 & 0.64634 \\
\hline
\end{tabular}

Valid N (list wise)

(Note: This table describes the overall mean of 52 students' responses about motivation)

Table 1 presents the average mean of eight factors; the number showing students' motivation was quite high $(\mathrm{M}=4.22, \mathrm{SD}=0.65)$.

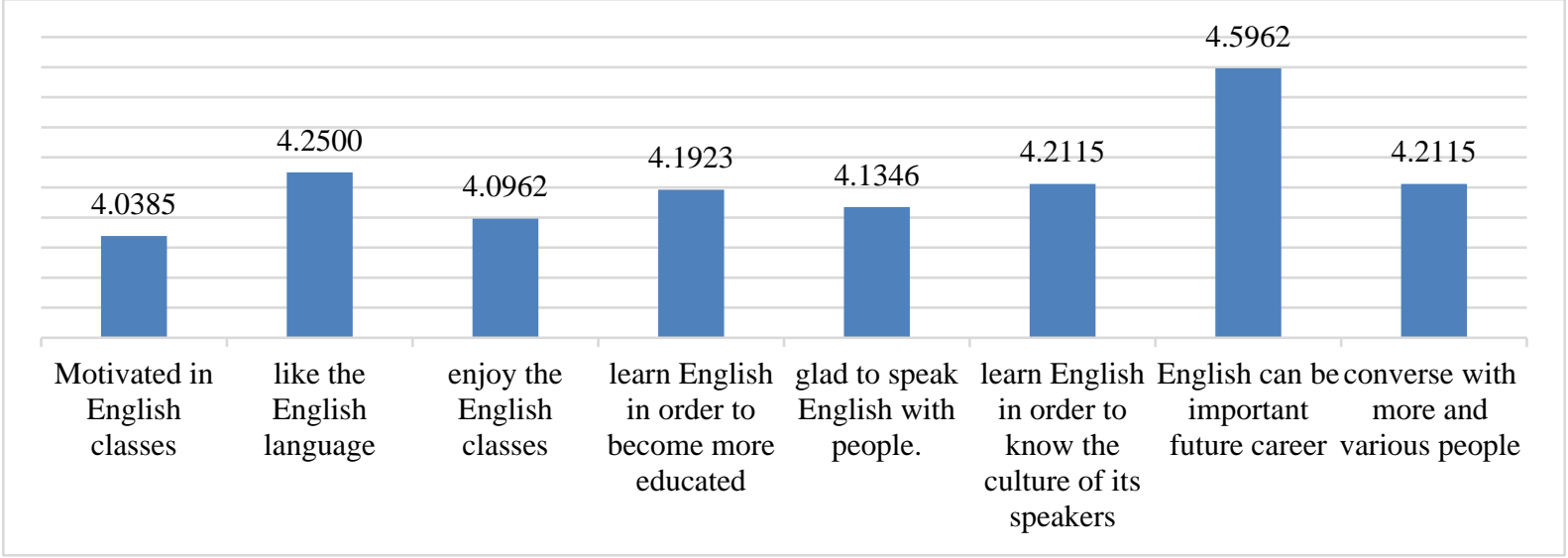

Figure 1. Responses given to motivation questions 
As can be seen, the sixth column "English can be important in my future career" obtained the mean of $M=4.60$, which came first on the list. Following the most preferred statement is "I like the English language", which reached the mean score of $M=4.25$. Besides, the two statements "I learn English in order to know the culture of its speaker" and "I can converse with more and various people when their language skills have become more advanced", were rated at the same level of $\mathrm{M}=4.21$.

4.1.3. Factors contributing to English majors' motivation in studying English

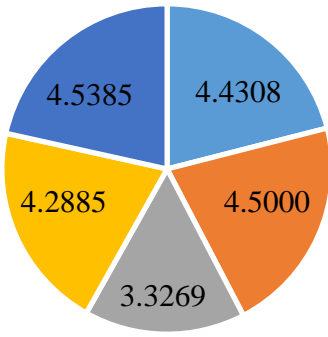

- Teacher is patient. $\quad-$ Teacher is friendly. $\quad$ Teacher is strict.

$=$ Teacher is fair. $\quad-$ Teacher is helpful.

Figure 2. Teacher's personalities

"Teacher is helpful" and "Teacher is friendly" obtained the mean scores of $\mathrm{M}=4.54$ and $\mathrm{M}=4.50$ respectively. By contrast, most of the students showed less inclination with "Teacher is strict" $(M=3.33)$. Friendly and helpful characteristics seemed to be of greater favour from the students.

Teacher brings up an interesting topic.

Teacher awards marks for classroom participation.

Teacher correct any mistakes I make.

Teacher uses English all the time.

Teacher knows more about general knowledge in.

Teacher tends to focus more on the knowledge in the.

Teacher explains everything to me.

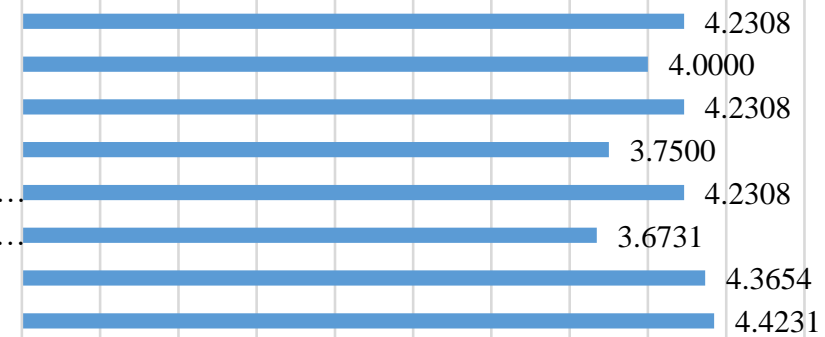

Teacher knows how to encourage us to study.

0.00000 .50001 .00001 .50002 .00002 .50003 .00003 .50004 .00004 .50005 .0000

\section{Figure 3. Teacher's methodology}

"Teacher knows how to encourage" and "Teacher explains everything" received the mean scores of $M=4.42$ and $\mathrm{M}=4.37$ respectively. "Teacher tends to focus more on the knowledge in the textbook" got low-ranking from the participants $(M=3.67)$.

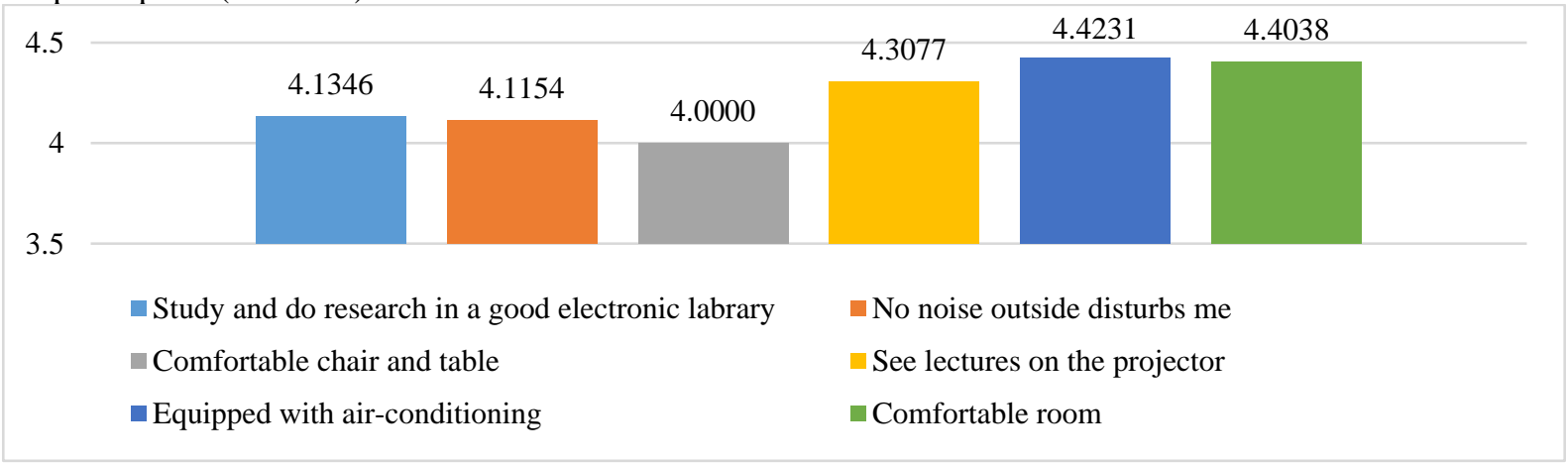

Figure 4. Facilities for study

"The room is equipped with air-conditioning" and "I am in a comfortable room" obtained a high level of rating, $M=4.42$ and $M=4.40$ respectively. Nonetheless, the statement "Sitting at a comfortable chair and table" did not receive high-rating by the participants $(\mathrm{M}=4.00)$. 


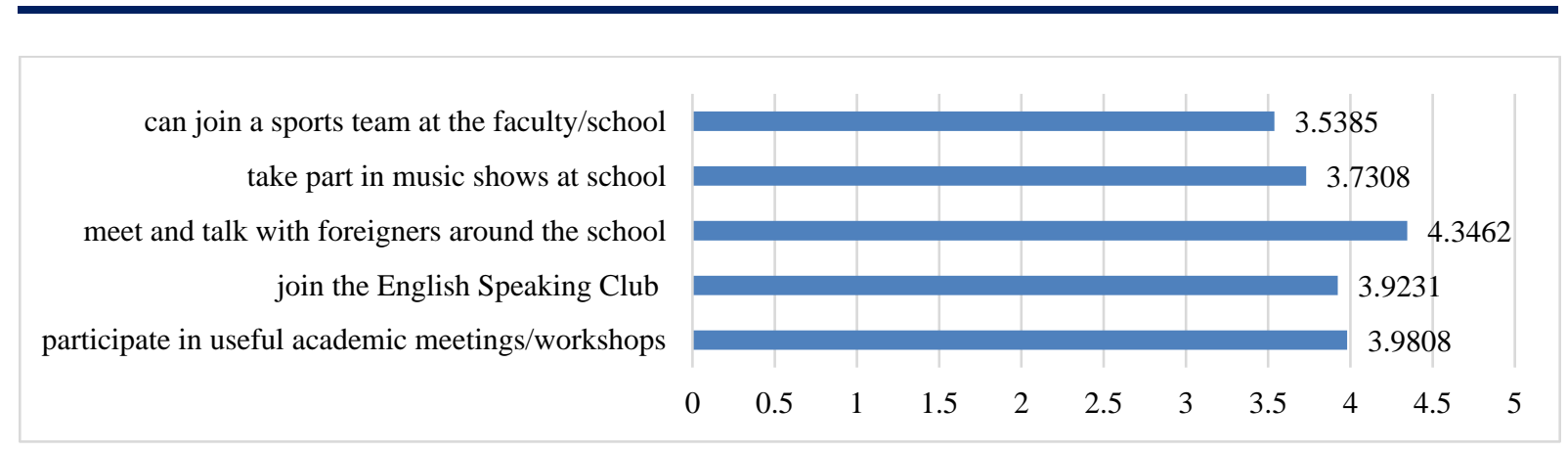

Figure 5. Activities in the faculty and school

This chart shows the means of the seven statements in this factor group. "I can meet and talk with foreigners around the school" reached the highest point in this factor group, $\mathrm{M}=4.53$. By contrast, "I can join a sports team at the faculty or school" received $\mathrm{M}=3.54$.

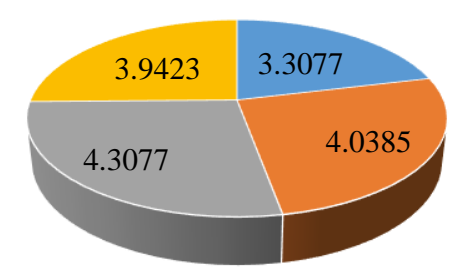

\footnotetext{
- Classmate and I are the same age. - Sick help from other friends

- Share ideas with friends around $\quad$ Sit next to a strong student
}

\section{Figure 6. Classmates}

As seen in Figure 6, the mean $M=4.31$ belonged to the statement "I can share ideas with friends around". In comparison, "I like to study when my classmates and I are at the same age" did not reach high approval in this factor group.

have more permitted absences in a class

have a long vacation after hard study

seek financial support from the faculty/school/charities

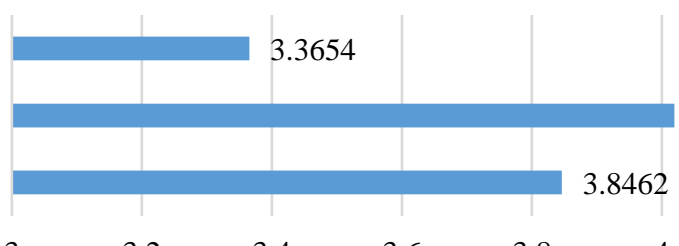

\section{Figure 7. Policies}

"I can have a long vacation after hard study." were widely preferred among respondents with $\mathrm{M}=4.02$ while "I have more permitted absences in class" just received a mean point of $\mathrm{M}=3.37$.

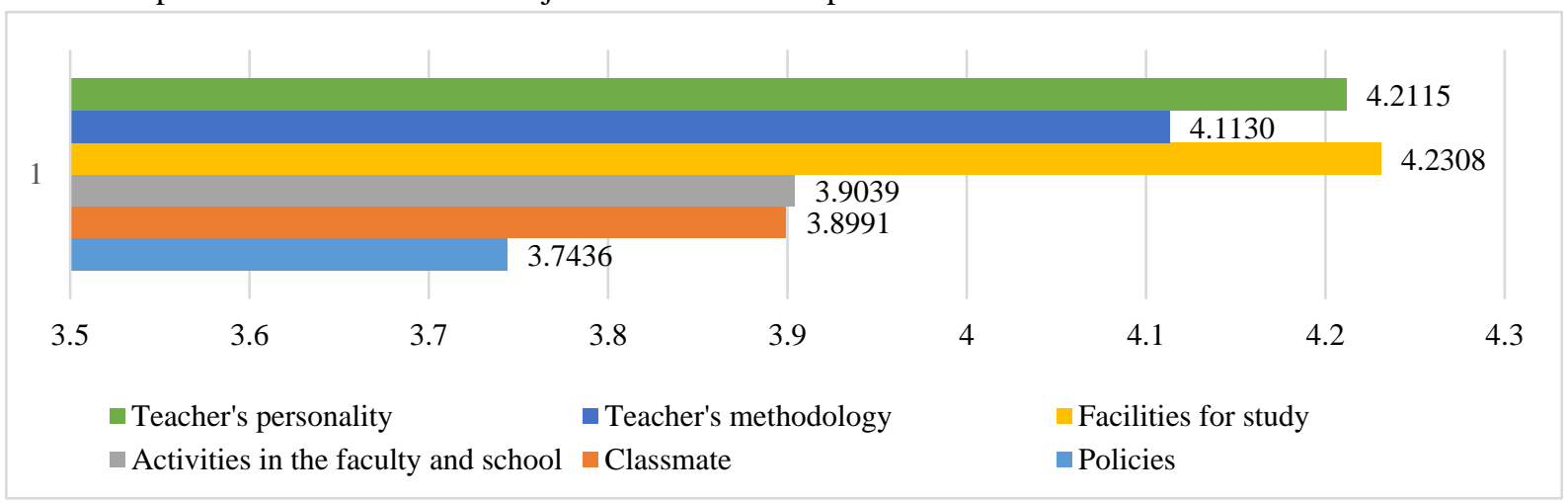

Figure 8. Mean average of six factors 
The factor "Facilities for study" received the highest mean $(\mathrm{M}=4.23)$. Following is the factor "Teacher's personality", which reached the point of $\mathrm{M}=4.21$. On the other hand, the factor "Policies" witnessed the lowest rate $(\mathrm{M}=3.74)$.

\subsection{Discussion}

To answer the first research question “Are English majors motivated to study English at university?". Yes, they are. As can be seen from the analysis of a five - point Likert scale, the $\mathrm{M}=4.2164, \mathrm{SD}=.64634$ indicates that most of the students are motivated during their university. They study English for many different purposes and the most remarkable finding is that they consider English a useful tool to help them advance their future career.

For the second research question "What factors can contribute to English majors' motivation in studying?", the reliability for the questionnaire is confirmed with the mean $\mathrm{M}=.845$, showing that it is reliable for further analysis. In other words, it can indicate that most learners realized the importance of English. In today's corporate world, the need for effective communication has been recognized and accepted more than technical knowledge. Thus, the statement "English can be important for my future career" verifies a significant influence on a learner's motivation which belongs to extrinsic motivation. Besides, the findings also revealed that English received much attention by these learners through the statement "I like the English language". To sum up, the great majority of English learners are extrinsically motivated in their class.

Moreover, the findings also illustrated what factors can contribute to English major's motivation in studying. Firstly, although students rated differently the levels of these important contributing factors towards the learners' motivation, the factor group "facilities for study" obtained the highest rating in this study. The reason for this highrating possibly came from the needs for favourable learning condition of the classroom. The classroom context may support the learners' desire to learn and demand for facilities in classroom; it also plays an integral part in encouraging students to make their best efforts to study. Classrooms with adequate equipment to serve the learning needs and comfortable environment are regarded as an indispensable factor to promote motivation in learning and studying foreign languages. Environmental factors also have a big influence on learners' motivation. Even though they try to motivate themselves, the environmental factors, such as classroom management, may impede them. For example, if the class is overcrowded and the classroom lack basic facilities such as lights, air-conditional, etc., students may definitely demotivated due to poor learning conditions (Le, 2012). On the contrary, he also added physical conditions such as lighting, positive atmosphere, seating arrangement, diverse visuals, and useful materials can foster learning. These should, in reality, worry many institutions in financial shortage.

Secondly, the two factors related to teachers namely teacher's personalities and teacher's methodology were rated roughly at the same level. As for language proficiency achievement, this factor is also effective to assist students in enhancing their motivation. The reason for this high-rating might come from the needs of the contact between the learners and teachers through the learning process. Learners' interest in school and desire for learning had an effect on such factors as teachers, instructors, and school circumstances. But when compared, teachers are seen to be an important factor due to the fact that they have an important role in conditioning their students' learning. Teacher's feedback influences students' learning language motivation when they realized that they followed individual development (Le, 2012). Berges (2018) also asserted that teachers' personality plays a role in motivating students to learn. Learners may need more supports and communication from their teachers than their classmates. However, this finding can incline to teaching methodology rather than concert factors; it is something from external influence. But according to Zilmaz et al. (2017), teachers' methodology and classroom management skills are crucial to promoting students' motivation.

Finally, the factor "classmates" and "activities in the faculty and school" are reported to be useful which obtain almost the same rating, so they should be applied frequently for all learners. The explanation may come from the desire for the connection between learners and their classmates. Besides, learners may receive supports from their friends. Nasser and Majid (2011) emphasised that developing a friendly atmosphere will make all students feel recognized and valued. The learners feel more comfortable when they are participating in classroom activities after knowing their peers. Moreover, building a safe and comfortable zone where everyone feels like a part of the whole is one of the most vital factors in encouraging motivation and facilitating students' positive attitude. Students learn new things in their classroom with their friends. That is why we cannot deny the effect of peers in the learning process. Furthermore, activities in the faculty and school are considered as a crucial way for learners to have more connection with each other in addition to studying in class. 
The result is quite similar to Branch (2016), who found that learners' motivation can go up and down depending on the context of language learning. Teachers can play a significant role in motivating learners to learn a second or foreign language. Motivation is an important factor in learning a foreign language which is influenced by different factors. MacIntyre (1999) believed that a safe classroom climate is necessary for motivation and learners feel comfortable to learn a language in this ideal condition. Good and Brophy (1994) stated that motivation cannot be developed in a difficult classroom and teachers should create an effective learning environment for their learners. The current study also showed that the majority of the students believed that English will be useful for their future career with $\mathrm{M}=4.60$, unveiling the broadest agreement in this motivation factor group. This resonates the result found by Perkins (2008) that the participants in his study also showed great agreement in this factor.

Overall, the two factors group that achieved the broadest agreement are teachers' personality and learning facilities, both obtained 4.2, over value 4. Noticeably, these students seem to be less concerned about the university policies. The mean score for this factor received only 3.7, meaning they are not very much aware of the policies. But in reality, these can dramatically affect a person's job and/ or academic performance.

\section{CONCLUSION}

The findings sufficiently address the research questions of the study. Overall, the participants in this study are motivated during their study at university. Learning facilities are found to be the most important factor group to boost these students' motivation. Besides, the teacher's personality and methodology also help motivate these learners because teachers are the people who directly inspire their students to learn in class. All in all, all factors can influence learners' motivation. The only difference is the level of motivation obtained by each factor and each factor group. Moreover, teachers have to create a supportive classroom atmosphere in which the teacher plays a role of a supporter or a facilitator who will contribute to improving motivation in class and therefore encouraging many more students to participate in classroom discussions and taking risks. Teachers should help their students to find motivation in the areas where they are still weak, so they can take advantage of it to boost the learning desire. Then, learners will learn better in a classroom where their teacher is friendly and helpful. They believe that these factors can greatly influence them. In addition to the teacher's personality, learners will learn best when they are equipped with modern and quality facilities. They pay tuition fees to be in classrooms and they pay to study with qualified teachers, so if the school or institution offers them a variety of wonderful facilities, they will no longer feel they are ignored and unappreciated.

Due to time limitation and limited number of the English-majors in the faculty, the present study could only focus on a small sample of 52 third-year and four-year English majors and we believe it would produce a more persuasive result when it involved a larger sample of students and it could even better to conduct a longitude study to measure their motivation and orientations during the campus life.

\section{REFERENCES}

Berges-Puyó, J. G. (2018). Motivational factors in learning an L2: A study on intrinsiclextrinsic motivation, classroom materials and teacher's behaviors. Retrieved from https://www.researchgate.net/publication/ 325204332_Motivational_factors_in_learning_an_L2_a_study_on_intrinsicextrinsic_motivation_classroom_m aterials_and_teacher\%27s_behaviors

Bernaus, M. \& Gardner, R. C. (2008). Teacher motivation strategies, student perceptions, student motivation, and English achievement. The Modern Language Journal, 92, 389-401.

Black, A. E., \& Deci, E. L. (2000). The effects of instructors' autonomy support and students' autonomous motivation on learning organic chemistry: A self-determination theory perspective. Science Education, 84, 740-756.

Branch, L. (2016). The impact of motivation on English language learning. International Journal of Research in English Education, 1(1), 11-15.

Brown, H. D. (2000). Principles of language learning and teaching (4 ${ }^{\text {th }}$ Ed.). International Journal of Research in English Education. Englewood Cliffs NJ: Prentice-Hall.

Broussard, S. C., \& Garrison, M. E. B. (2004). The relationship between classroom motivation and academic achievement in elementary school-aged children. Family and Consumer Sciences Research Journal, 33(2), 106-120.

Brown, H. D. \& Gonzo, T. (1995). Principles of languages teaching and learning. San Francisco: Prentice Hall Regents.

Crookes, G., \& Schmidt, R. W. (1991). Motivation: Reopening the research agenda. Language Learning, 41, 469-512.

Ditual, R. C. (2012). The motivation for and attitude towards learning English. Asian EFL Journal, 63, 12-14.

Dörnyei, Z. (1996). Moving language learning motivation to a longer platform for theory and practice. In: Oxford. 
Dörnyei, Z. (1998). Conceptualizing motivation in foreign language learning. Language Learning, 40, 46-78.

Dörnyei, Z. (2001). Teaching and researching: Motivation. London: Routledge.

Ellliot, A. J. \& Covington, M. (2001). Approach and avoidance motivation. Educational Psychology Review, 13(2). 23-24.

Falk, J. (1978). Linguistics and language: A survey of basic concepts and implications (2 ${ }^{\text {nd }}$ Ed.). John Wiley and Sons.

Gardner, R. C. (1985). Social psychology and language learning: The role of attitudes and motivation. London: Edward Arnold.

Gardner, R. C. \& Lambert, W. (1972). Attitudes and motivation in second language learning. Rowley, Mass: Newbury.

Good, T. L. \& Brophy, J. E. (1994). Looking in classrooms. New York: Harper Collins.

Guay, F., Chanal, J., Ratelle, C. F., Marsh, H. W., Larose, S. \& Boivin, M. (2010). Intrinsic, identified, and controlled types of motivation for school subjects in young elementary school children. British Journal of Educational Psychology, 80(4), 711-735.

Heidari, K. \& Riahipour, P. (2012). Demotivating factors on English speaking skill: A study of EFL language learners and teachers' attitudes. World Applied Sciences Journal, 17, 327-339.

Huitt, W. (2001). Motivation to learn: An overview. http://chiron.valdosta.edu/whuitt/col/motivation/motivate.html

Khau, H. A. \& Huynh, N. (2016). Motivation for Vietnamese Non-English Majors Learning General English at Tra Vinh University. In the 2016 Symposium: English Language Teaching, Vietnamese Context, 90-91. School of Foreign Languages, Tra Vinh University, Vietnam.

Krashen, S. D. (1976). Formal and informal linguistic environments in language learning and language acquisition. TESOL Quarterly, 10, 157-168.

Le, T. T. (2012). An empirical research into EFL learners' motivation. Theory and Practice in Language Studies, 2(3), 430-439.

Lightbown, P. M. \& Spada, N. (2006). How languages are learned. New York: Oxford University Press.

MacIntyre, P. D. \& Doucette, J. (2010). Willingness to communicate and action control. System, 38, 161-171.

Miserandino, M. (1996). Children who do well in school: Individual differences in perceived competence and autonomy in above-average children. Journal of Educational Psychology, 88(2), 203-214.

Nakata, Y. (2006). Motivation and experience in foreign language learning. Oxford: Peter Lang AG.

MacIntyre, P. D., \& Noel, K. A. (1996). Using social-psychological variables to predict the use of language learning strategies. Foreign Language Annals, 29, 373-386. https://doi.org/10.1111/j.1944-9720.1996.tb01249.x

Nasser, O. \& Majid, V. (2011). Motivation, attitude, and language learning. Procedia - Social and Behavioral Sciences, 29, 994-1000.

Oxford, R., \& Shearin, J. (1994). Language learning motivation: Expanding the theoretical framework. Modern Language Journal, 78, 12-28.

Pardee, R. L. (1990). Motivation theories of Maslow, Herzberg, Mcgregor and Mcclelland. A literature review of selected theories dealing with job satisfaction and motivation. Eric, 1-24.

Perkins, J. (2008). Intrinsic or instrumental: Motivational characteristics of English language learners in Japan. Eric, 1-22.

Pourhosein G. A., Leong, L. M., \& Saburi, N. B. (2012). Study on the Role of Motivation in Foreign Language Learning and Teaching. I.J. Modern Education and Computer Science, 7, 9-16.

Seda, E. \& Zahitjan, K. (2016). The factors affecting learners' motivation in English language education. Journal of Foreign Language Education and Technology, 1(1), 14-15.

Sugita, M., \& Takeuchi, O. (2010). What can teacher do to motivate their students? A classroom research on motivational strategy use in Japanese EFL context. Innovation in Language Learning and Teaching, 4(1), 21-35.

Zilmaz, E., Sahin, M. \& Turgut, M. (2017). Variables affecting students' motivation based on academic publications. Journal of Education and Practice, 8(12), 112-120. 